\section{Analisis Pengaruh Kualitas Layanan terhadap Kepuasan Konsumen pada PT. Asuransi Jasa Indonesia Cabang Medan}

\section{Irianif Sani}

Universitas Harapan Medan

saniyansen@gmail.com

Saskia ${ }^{2)}$,

Universitas Harapan Medan

saskiayusuf@gmail.com

Syahyunan ${ }^{3)}$

Universitas Harapan Medan

syahyunan4966@gmail.com

\begin{abstract}
Abstrak Penelitian ini bertujuan untuk mengetahui besarnya pengaruh dan signifikansi kualitas layanan yang meliputi tangible, reliability, responsiveness, assurance dan empathy terhadap kepuasan konsumen pada PT. Asuransi Jasa Indonesia cabang Medan. Penelitian ini mengunakan metode penelitian kuantitatif dengan data populasi sebanyak 29.469 polis/konsumen dari Tahun 2015-2019 yang berasal dari agen, broker dan perorangan (umum). Teknik pengumpulan data yang dilakukan adalah dengan cara menyusun daftar pertanyaan sesuai dengan variabel dan indikator masalah yang diteliti kemudian disebarkan kepada responden agen dan broker sebanyak 394 responden. Hasil penelitian ini diperoleh nilai signifikansi kualitas layanan tagible sebesar 0.602, kualitas layanan reliability sebesar 0,564, kualitas layanan responsiveness sebesar 0,352, kualitas layanan assurance sebesar 0,756 dan nilai signifikansi kualitas layanan empathy dengan nilai t tabel sebesar $-0,232$ dan nilai signifikansi sebesar 0,819 . Kualitas layanan tangible, reliability, responsiveness, assurance berpengaruh positif dan signifikan terhadap kepuasan konsumen. Sedangkan kualitas layanan empathy berpengaruh negatif dan signifikan terhadap kepuasan konsumen. Hasil nilai R Square adalah 0,785, sehingga besarnya pengaruh variabel kualitas layanan terhadap kepuasan konsumen adalah $78,5 \%$ sedangkan sisanya $21,5 \%$ dipengaruhi oleh variabel lain di luar penelitian.
\end{abstract}

Kata Kunci Kualitas Layanan, Kepuasan Konsumen, Asuransi Jasa Indonesia

\section{PENDAHULUAN}

Di dalam bidang usaha asuransi pihak perusahaan selalu menjaga dan mengutamakan kualitas layanan terhadap konsumennya. Hal yang mendasar di dalam layanan kepada konsumen adalah mudah dan cepat dalam melakukan klaim asuransi dan konsumen merasakan manfaat berasuransi diperusahaan tersebut. Dengan layanan klaim yang mudah 


\section{JESYA}

JURNAL EKONOMI \& EKONOMI SYARIAH

Jurnal Ekonomi \& Ekonomi Syariah Vol 5 No 1, Januari 2022

E-ISSN : 2599-3410 | P-ISSN : 2614-3259

DOI : https://doi.org/10.36778/jesya.v5i1.580

dan cepat di saat konsumen mengalami musibah ataupun kerugian yang telah ditimbulkan dapat menciptakan kepuasan tersendiri bagi para konsumen.

Kualitas layanan adalah kunci keberhasilan dari setiap perusahaan untuk meraih keunggulan yang berkelanjutan. Kualitas layanan merupakan salah satu kunci keberhasilan dari setiap bisnis. Kualitas ini bertujuan untuk memenuhi ekspektasi atau harapan pelanggan dengan menyediakan layanan dan produk dari tingkat nilai produk itu sendiri”. Perusahaan harus mempertimbangkan terhadap kepuasan konsumen selain mencari keuntungan. Sehingga perusahaan harus memperhatikan dalam memberikan layanan, perusahaan harus melakukan interaksi pada setiap konsumen secara langsung yang bertujuan untuk memperoleh umpan balik (feed back) berupa tanggapan konsumen tentang sarana dan prasarana yang berhubungan dengan layanan yang diberikan sebagai indikator dalam mencapai kepuasan yang diharapkan oleh setiap konsumen. Nur (2016:4).

Kualitas layanan sering dijadikan sebagai tolak ukur dimana kualitas layanan adalah perbandingan harapan yang diinginkan oleh konsumen dengan layanan yang dibutuhkan kepada para konsumen. Kualitas layanan yang dirasakan oleh konsumen dapat diukur melalui dimensi kualitas layanan. Menurut Tjiptono (2004:273) Dimensi kualitas layanan terbagi menjadi lima dimensi adalah sebagai berikut: bukti fisik (tangibles), kehandalan (reliability), ketanggapan (responsiveness), jaminan (assurance) dan empati (emphaty). Layanan yang berkualitas dan tingkat kepuasan yang dirasakan terhadap para konsumen juga akan berdampak dengan meningkatnya jumlah konsumen pada perusahaan tersebut.

Saat ini perilaku konsumen semakin jeli dalam memilih perusahaan asuransi yang memilih pada perusahaan yang memberikan layanan terbaik serta memberikan kepuasan dalam menyediakan produk asuransi. Maka demikian layananan menjadi hal yang sangat riskan demi terwujudnya keinginan dan kepuasan pada setiap konsumen. Dengan kualitas layanan yang cukup memuaskan adalah suatu daya tarik kepada konsumen untuk tidak akan melirik ke perusahaan asuransi lain, sehingga konsumen lama akan tetap bertahan dan konsumen yang baru akan mencoba produk perusahaan asuransi tersebut.

Setiap konsumen mempunyai kriteria masing-masing dalam memilih perusahaan asuransi yang diinginkan baik itu dari harga premi terjangkau hingga perusahaan bisa memberikan keuntungan yang lebih besar, efisien, baik, dan layanan yang lebih cepat. Menurut Tjiptono dan Chandra (Dalam Raharja 2005:2) keunggulan layanan memiliki empat pilar yang saling terkait yaitu: (1) kecepatan, (2) ketepatan, (3) keramahan dan (4) kenyamanan. Jadi, kualitas layanan adalah nilai-nilai terkandung dalam layanan terhadap orang lain. Hal yang perlu diperhatikan dalam meningkatkan kualitas layanan dalam perusahaan adalah memberikan tingkat kepuasan konsumen.

Menurut Kotler (2009:140) bahwa banyak perusahaan secara sistematis mengukur faktor-faktor yang membentuk kepuasan terhadap konsumen. Salah satu faktor yang membentuk kepuasan adalah dengan kualitas layanan terbaik kepada konsumen. Cara yang paling sederhana untuk mengukur kepuasan konsumen adalah dengan menanyakannya langsung kepada konsumen apakah mereka puas dengan produk atau jasa perusahaan tersebut. Cara mengukur tingkat kepuasan konsumen terhadap produk atau jasa perusahaan tersebut dengan membandingkan tingkat kepuasan para konsumen terhadap produk para pesaing. Kepuasan konsumen melalui kualitas layanan yang baik merupakan tanggung jawab manajemen dan seluruh karyawan dengan selalu berusaha untuk mengetahui dan memahami kebutuhan yang diinginkan oleh seluruh konsumen.

PT. Asuransi Jasa Indonesia (Persero) adalah Badan Usaha Milik Negara (BUMN) yang bergerak di bidang asuransi yang dibentuk berdasarkan Peraturan Pemerintah No. 10 Tahun 1973 tentang Penyertaan Modal Negara untuk Pendirian Perusahaan Perseroan dalam Bidang Asuransi Umum. Perusahaan ini menjalankan usahanya pada tahun 1973, sampai 


\section{JESYA}

JURNAL EKONOMI \& EKONOMI SYARIAH

Jurnal Ekonomi \& Ekonomi Syariah Vol 5 No 1, Januari 2022

E-ISSN : 2599-3410 | P-ISSN : 2614-3259

DOI : https://doi.org/10.36778/jesya.v5i1.580

saat ini perusahaan tersebut memiliki jaringan 41 Branch Offices dan 33 Satellite Branch Offices yang tersebar di seluruh Indonesia. PT. Asuransi Jasa Indonesia cabang Medan adalah salah satu kantor cabang dari 89 kantor di seluruh wilayah Indonesia. PT. Asuransi Jasa Indonesia merupakan $100 \%$ perusahaan milik Pemerintah Indonesia, sehingga memberikan kepastian untuk melayani konsumen.

Tujuan dari penelitian ini adalah untuk menguji dan menganalisis besarnya pengaruh dan signifikansi kualitas layanan yang meliputi tangible, reliability, responsiveness, assurance dan empathy terhadap kepuasan konsumen asuransi kerugian pada PT. Asuransi Jasa Indonesia cabang Medan. Adapun manfaat dari penelitian ini adalah dapat menambah pengetahuan dalam menganalisa persoalan mengenai mutu tangible, reliability, responsiveness, assurance dan empathy terhadap kepuasan konsumen pada PT. Asuransi Jasa Indonesia cabang Medan. Penelitian ini dapat menjadi rekomendasi bagi pihak asuransi dalam usaha meningkatkan kualitas layanan agar lebih memuaskan konsumen serta untuk mempertahankan tingkat layanan khususya di PT. Asuransi Jasa Indonesia cabang Medan.

\section{TINJAUAN PUSTAKA}

\section{Kualitas Layanan}

Dalam industri asuransi, setiap konsumen memiliki kriteria sendiri-sendiri untuk memilih perusahaan asuransi yang diinginkannya. Ada yang menginginkan suatu perusahaan asuransi bisa memberikan keuntungan lebih selain proteksi diri seperti bunga investasi yang tinggi. Ada pula konsumen yang menginginkan layanan yang lebih cepat, efisien, baik, dan harga yang ditawarkan sesuai dengan yang didapat nantinya.

Kualitas layanan adalah suatu aktivitas atau serangkaian aktivitas yang bersifat tidak kasat mata yang terjadi sebagai akibat adanya interaksi antara konsumen dengan karyawan atau hal-hal lain yang berkaitan dengan layanan. Interaksi ini disediakan oleh perusahaan pemberi layanan yang dimaksudkan untuk memecahkan permasalahan konsumen, sehingga mampu memenuhi atau bahkan melebihi harapan konsumen.

Zeithaml et al dalam Haris (2017:144) menemukan bahwa ada lima penentu kualitas jasa sesuai dengan tingkat kepentingan konsumen sebagai berikut:

a. Bukti Fisik (tangibles) dimensi ini berhubungan dengan penampilan personal maupun fasilitas fisik bangunan, seperti kondisi peralatan kantor atau perlengkapan kantor asuransi baik atau layak digunakan, kondisi sarana seperti bangunan, penampilan pegawai, perlengkapan dan sarana komunikasi. Bagi perusahaan yang bergerak dalam bidang jasa, layanan yang dikerjakan secara professional akan memberikan keuntungan yang besar bagi perusahaan.

b. Reliabilitas (reliability) Kemampuan perusahaan untuk melaksanakan layanan yang dijanjikan secara akurat dan terpercaya. Terutama memberikan jasa secara tepat waktu dengan jadwal yang telah dijanjikan kepada konsumen tanpa melakukan kesalahan.

c. Ketanggapan (responsiveness) Berkenan dengan kesediaan dan kemampuan untuk membantu pengguna jasa dan merespon yang dibutuhkannya dengan cepat. Tidak membiarkan konsumen menunggu, yang akan menimbulkan kesan negatif. Sehingga konsumen menjadi berkesan dan memiliki pengalaman yang indah.

d. Jaminan (assurance) Jaminan mencakup pengetahuan, kompetensi, kesopanan, dan sifat yang dapat dipercaya. Jaminan juga bebas dari bahaya dan menghilangkan kesan keragu-raguan konsumen. Pengetahuan dan kesopanan pegawai serta kemampuan mereka untuk menimbulkan keyakinan dan kepercayaan pengguna jasa.

e. Empati (empathy) perusahaan bersedia untuk peduli dan memberi perhatian tulus kepada konsumen dengan berupaya memahami keinginan konsumen. Perusahaan harus 


\section{JESYA}

JURNAL EKONOMI \& EKONOMI SYARIAH

Jurnal Ekonomi \& Ekonomi Syariah Vol 5 No 1, Januari 2022

E-ISSN : 2599-3410 | P-ISSN : 2614-3259

DOI : https://doi.org/10.36778/jesya.v5i1.580

memiliki suatu pengetahuan dan pemahaman tentang konsumen dan mengetahui

kebutuhan konsumen secara khusus pada saat memberikan layanan.

Konsumen akan menentukan pilihan dan merasa puas pada perusahaan asuransi yang mampu memberikan layanan yang baik, karena mereka menggunakan jasa asuransi dalam jangka waktu tertentu, sehingga layanan menjadi penting dalam memenuhi kepuasan konsumen. Suatu perusahaan asuransi harus dapat memberikan layanan yang terbaik, cepat, profesional, dan fleksibel kepada konsumennya. Meningkatkan kualitas layanan dan memuaskan konsumen merupakan tujuan dari setiap perusahaan jasa maupun perusahaan lainnya. Pernyataan ini sesuai menurut Gardenia dalam Anggabrata, dan Rahanata. (2015:2). Kualitas pelayanan sering dikonseptualisasikan sebagai perbandingan antara layanan yang diharapkan dengan persepsi performansi yang diterima.

Sedangkan menurut Yonggui dalam Anggabrata, dan Rahanata. (2004:125) menyatakan bahwa bagi suatu perusahaan khususnya perusahaan jasa, kualitas pelayanan sangat mempengaruhi tingkat kepuasan konsumen. Sehingga bagi perusahaan jasa sangatlah penting untuk mengatur strategi bagaimana meningkatkan kualitas pelayanan agar kepuasan konsumen dapat tercipta. Maka dari itu perusahaan harus mampu dalam menciptakan suatu produk dan layanan yang terbaik agar terciptanya kepuasan setiap konsumen.

\section{Kepuasan Konsumen}

Pada dasarnya tujuan dari suatu perusahaan adalah memberikan layanan terbaik untuk membuat konsumen merasa terpuaskan. Semakin tinggi tingkat kepuasan konsumen, maka akan mendatangkan keuntungan yang semakin besar bagi perusahaan, karena konsumen akan melakukan pemakaian ulang terhadap produk perusahaan tersebut. Namun, apabila tingkat kepuasan yang dirasakan konsumen kecil, maka terdapat kemungkinan bahwa konsumen tersebut akan pindah ke produk pesaing. Menurut Kotler, kepuasan konsumen (customer) adalah tingkat perasaan seseorang setelah membandingkan kinerja atau hasil yang dia rasakan dibandingkan dengan harapannya (Kotler dkk, 2000:52).

Menurut Dutka dalam Suryawan (2008:4) mendefinisikan kepuasan adalah "Satisfied customer improve business and dissatisfied customer impair business". Jadi sesungguhnya ini merupakan hal yang tidak mudah, bagaimana menciptakan kepuasan sekaligus mempertahankan kepuasan konsumen tersebut. Ketidakpuasan konsumen akan menyebabkan perusahaan sulit untuk bertahan dalam menghadapi persaingan.

Hal ini sesuai dengan definisi yang dikatakan Dutka (2008:211) yang menyatakan "Satisfied customer are absolutely vital to business success.". Konsumen akan merasa puas apabila harapannya terpenuhi. Harapan yang dimaksud disini adalah persepsi konsumen sebelum dan sesudah menggunakan suatu produk.

Menurut Tjiptono (2007:24) merupakan evaluasi purna beli dimana alternatif yang dipilih sekurang-kurangnya sama atau melampaui harapan konsumen, sedangkan ketidakpuasan timbul apabila hasil (outcome) tidak memenuhi harapan. Dalam pembentukannya, kepuasan konsumen mengacu kepada beberapa indikator antara lain sebagai berikut: (1) Perasaan Puas yang dirasakan oleh konsumen (2) Kesesuaian harapan yang diberikan dengan yang diharapkan oleh konsumen (3) Kesediaan konsumen untuk merekomendasikan kepada saudara, rekan, teman sejawat maupun yang lainnya (4) Keberlanjutan konsumen dalam membeli produk.

Sedangkan Menurut Kotler (1997) (Dalam Tjiptono 2004:147). Kepuasan konsumen merupakan perasaan senang atau kecewa seseorang yang berasal dari perbandingan antara pengalamannya atas kinerja suatu produk dan harapan-harapannya. Sedangkan pengertian lain menyebutkan bahwa kepuasan konsumen adalah sejauh mana manfaat sebuah produk dirasakan sesuai dengan apa yang diharapkan konsumen. Sehingga kepuasan merupakan 
fungsi dari kinerja dan harapan. Jika kinerja dibawah harapan konsumen tidak puas. Tetapi jika sebaliknya, kinerja melebihi harapan maka konsumen akan merasa puas.

Menurut Kotler dan Keller (2009:140) Ada empat metode yang sering digunakan dalam pengukuran kepuasan konsumen adalah sebagai berikut :

1) Sistem keluhan dan saran

Perusahaan membuat kotak keluhan dan saran kepada konsumen untuk mengetahui pendapat secara langsung atas jasa layanan yang telah diberikan oleh perusahaan tersebut. Kotak keluhan dan saran ini ditempatkan di tempat yang mudah terjangkau oleh konsumen seperti di ruang tungggu pintu ruangan administrasi sehingga konsumen dapat menuliskan langsung pendapatnya dan dimasukkan kedalam kotak tersebut.

\section{2) Ghost Shopping}

Adapun metode Ghost Shopping ini ialah suatu cara menilai tingkat kepuasan konsumen dengan memperkerjakan beberapa orang (Ghost shopper) yang berperan sebagai konsumen potensial pada produk perusahaan pesaing. Ghost shopper dimintai melaporkan hasil temuan-temuannya terkait kelemahan dan kekuatan produk perusahaan pesaing setelah produk tersebut keseluruhan yang mereka beli dan mereka evaluasi.

\section{3) Lost Costumers Analysis}

Metode survey ini merupakan pengukuran kepuasan konsumen dengan cara menghubungi konsumen yang lama yang telah berhenti menjadi konsumen dan beralih ke perusahaan pesaing. Perusahaan menghubungi konsumen tersebut dengan tujuan untuk memperoleh informasi penyebab berhentinya menjadi konsumen.

\section{4) Survei Kepuasan Konsumen}

Pada umumnya perusahaan asuransi sering melakukan survei kepada setiap konsumennya agar mendapatkan respon dan umpan balik secara langsung. Survei ini biasanya menghubungi konsumen baik dilakukan secara telepon maupun langsung, door to door, maupun media komunikasi via email.

Kepuasan konsumen adalah perbandingan antara harapan pembeli dengan suatu produk tersebut dengan manfaat yang telah diberikannya. Apabila produk tersebut dibawah harapan konsumen, maka konsumen tersebut merasa tidak puas ataupun merasa kecewa dan jika melebihi ataupun memenuhi dengan harapan maka konsumen tersebut merasa puas. Dengan memberikan kepuasan terhadap konsumen, maka konsumen tetap setia dalam melakukan pembelian produk tersebut.

Menurut Simamora (2007:1-2) Didalam membangun kepuasan konsumen, kualitas layanan merupakan salah satu faktor kunci keberhasilan sebagai perusahaan jasa dan tidak dapat dipungkiri dalam dunia bisnis saat ini, karena tidak ada yang lebih penting lagi bagi suatu perusahaan menempatkan masalah kepuasan terhadap konsumen melalui layanan sebagai salah satu komitmen bisnis. Jika layanan yang diberikan kepada konsumen itu baik dan memuaskan maka akan mempunyai pengaruh positif terhadap kinerja usaha, sebaliknya layanan yang diberikan kepada nasabah kurang memuaskan maka akan berpengaruh negatif terhadap kinerja usaha.

Di dalam Penelitian ini, peneliti menganalisis pengaruh kualitas layanan terhadap kepuasan konsumen pada PT. Asuransi Jasa Indonesia cabang Medan dengan menggunakan pendekatan kualitas layanan. Berdasarkan Data yang telah di peroleh, bahwa data tersebut menunjukan bersifat pluktuatif atau keadaan dimana kondisi terjadinya naik turunnya jumlah pemegang polis dari tahun 2015 - 2019. 


\section{JESYA}

JURNAL EKONOMI \& EKONOMI SYARIAH

Jurnal Ekonomi \& Ekonomi Syariah Vol 5 No 1, Januari 2022

E-ISSN : 2599-3410 | P-ISSN : 2614-3259

DOI : https://doi.org/10.36778/jesya.v5i1.580

Berdasarkan kutipan Parasuraman (Tjiptono 1997) (dalam Muttaqin 2013:2) mengemukakan bahwa dalam mengevaluasi jasa yang bersifat intangible, konsumen umumnya menggunakan atribut: (1) Bukti langsung (tangibles), meliputi fasilitas fisik, perlengkapan, pegawai dan sarana komunikasi. (2) Keandalan (reliability), yakni kemampuan memberikan pelayanan yang dijanjikan dengan segera, akurat dan memuaskan. (3) Daya tanggap (responsibility), yaitu keinginan para staff dan karyawan untuk membantu para konsumen dalam memberikan pelayanan dengan tanggap. (4) Jaminan (assurance), mencakup pengetahuan, kemampuan, kesopanan, dan sifat dapat dipercaya yang dimiliki para staff, bebas dari bahaya, resiko atau keragu-raguan. (5) Empati (empathy), adalah kemudahan dalam bekomunikasi yang baik, perhatian pribadi, dan memahami kebutuhan para konsumen.

\section{Hipotesis Penelitian}

Hipotesa merupakan suatu perumusan sementara mengenai suatu hal yang dibuat untuk menjelaskan hal itu dan juga untuk menuntun/mengarahkan penyelidikan selanjutnya. Berdasarkan tinjauan diatas maka hipotesis yang akan diuji dalam penelitian ini adalah :

1. Kualitas tangible berpengaruh positif dan signifikan terhadap kepuasan konsumen pada PT. Asuransi Jasa Indonesia cabang Medan.

2. Kualitas reliability berpengaruh positif dan signifikan terhadap kepuasan konsumen pada PT. Asuransi Jasa Indonesia cabang Medan.

3. Kualitas responsiveness berpengaruh positif dan signifikan terhadap kepuasan konsumen pada PT. Asuransi Jasa Indonesia cabang Medan.

4. Kualitas assurance berpengaruh positif dan signifikan terhadap kepuasan konsumen pada PT. Asuransi Jasa Indonesia cabang Medan.

5. Kualitas empathy berpengaruh positif dan signifikan terhadap kepuasan konsumen pada PT. Asuransi Jasa Indonesia cabang Medan.

\section{METODE PENELITIAN}

Metode penelitian yang digunakan adalah metode penelitian kuantitatif. Pengumpulan data menggunakan instrumen penelitian, analisis data bersifat kuantitatif atau statistik dengan tujuan untuk menguji hipotesis yang telah ditetapkan. Untuk mendapatkan hasil dalam penelitian ini, tipe penelitian yang digunakan adalah penelitian kuantitatif dengan pendekatan survei, yaitu penelitian yang mengambil sampel dari populasi dan menggunakan kuesioner sebagai alat pengumpulan data.

Populasi dari penelitian ini adalah jumlah polis asuransi dari agen dan broker dari tahun 2015-2019 yang berjumlah 395 orang.

Tabel 3.1. Tabel Proporsional

\begin{tabular}{cccc}
\hline \multirow{2}{*}{ Tahun Polis } & \multicolumn{2}{c}{ Jenis Polis } & \multirow{2}{*}{ Jumlah Polis } \\
\cline { 2 - 3 } & Polis Korporasi & Polis Ritel & 69 \\
2015 & 39 & 30 & 59 \\
2016 & 30 & 29 & 61 \\
2017 & 30 & 31 & 112 \\
2018 & 60 & 52 & 93 \\
2019 & 40 & 53 & 395 \\
\hline Total Polis & 199 & 196 & \\
\hline
\end{tabular}

Sumber: Data primer diolah (2021) 
Untuk menentukan jumlah sampel dalam penelitian ini, maka peneliti menggunakan rumus Taro Yaname dan Slovin, adapun penulis mengambil rumus ini berdasarkan pendapat Riduwan dan Engkos (2011:49) menyatakan bahwa "teknik pengambilan sampel menggunakan rumus dari Taro Yaname dan Slovin apabila populasinya sudah diketahui" sehingga dapat dirumuskan sebagai berikut:

Rumus:

Keterangan: $\mathrm{n}=$ Jumlah Sampel

$$
\mathrm{n}=\frac{N}{N \cdot d^{2}+1}
$$

$$
\begin{aligned}
& \mathrm{N}=\text { Jumlah Populasi / (29469) } \\
& \mathrm{d}^{2}=\text { Presisi / }(5 \%)
\end{aligned}
$$

Sehingga Sampel $(\mathrm{n})$ adalah: $\mathrm{n}=\frac{29469}{29469 \cdot(0,05)^{2}+1}$

$$
\begin{aligned}
& =\frac{29469}{29469 \cdot(0,5)^{2}+1}=394.64 \\
& \approx \text { dibulatkan menjadi } 395 \text { orang. }
\end{aligned}
$$

Dalam menentukan Sampel penelitian antara Perbandingan Polis Korporasi dengan Polis Ritel, berdasarkan tabel dibawah ini:

Tabel 3.2 Underwriting Profile Tahun Berjalan Tahun 2015 - 2019

\begin{tabular}{cccc}
\hline \multirow{2}{*}{ Tahun Polis } & \multicolumn{2}{c}{ Jenis Polis } & \multirow{2}{*}{ Jumlah Polis } \\
\cline { 2 - 3 } & Polis Korporasi & Polis Ritel & 5154 \\
2015 & 351 & 4803 & 4408 \\
2016 & 381 & 4027 & 4563 \\
2017 & 375 & 4188 & 8390 \\
2018 & 441 & 7949 & 6954 \\
\hline Total Polis & 462 & 6492 & 29.469 \\
\hline
\end{tabular}

Sumber: Underwriting Profile Tahun Berjalan; Pgm: UDW 0060 PT. Asuransi Jasa Indonesia Kantor Cabang Medan

Berdasarkan tabel tersebut sampel polis korporasi dengan polis Ritel 5 tahun terakhir adalah sebagai berikut:

a. Berdasarkan data Korporasi $\frac{2010}{29469} \times 395=26.94 \approx 27$

b. Berdasarkan data Ritel $\frac{27459}{29469} \times 395=368.05 \approx 368$

$$
=27+368=395
$$

Sehingga pengambilan unsur-unsur sampel berstrata secara proporsional adalah dengan menggunakan rumus alokasi proporsional:

$$
\mathrm{n}_{\mathrm{h}}=\frac{N_{h}}{N} \cdot n
$$

Keterangan: $\mathrm{n}_{\mathrm{h}}=$ jumlah unsur-unsur sampel menurut strata

$\mathrm{n} \quad=$ jumlah unsur-unsur sampel keseluruhan

$\mathrm{Ni}=$ jumlah unsur-unsur populasi berdasarkan strata

$\mathrm{N}$ = jumlah unsur-unsur populasi keseluruhan

Maka jumlah setiap unsur-unsur sampel dapat ditentukan sebagai berikut:

$$
\begin{aligned}
& \text { Polis Tahun } 2015=\frac{5154}{29469} \cdot 395=69,08=69 \\
& \text { Polis Tahun } 2016=\frac{4408}{29469} \cdot 395=59,08=59
\end{aligned}
$$




$$
\begin{aligned}
& \text { Polis Tahun } 2017=\frac{4563}{29469} \cdot 395=61,16=61 \\
& \text { Polis Tahun } 2018=\frac{8390}{29469} \cdot 395=112,45=112 \\
& \text { Polis Tahun } 2019=\frac{6954}{29469} \cdot 395=93,21=93
\end{aligned}
$$

Unsur-unsur sampel diberikan kode, jika yang berasal dari Agen maka diberi kode A1 - An, jika dari Broker maka pengodean diberi B1 - Bn, dan Umum diberikan kode U1 - Un sehingga sampel telah ditentukan secara proporsional.

\section{Teknik Pengumpulan Data}

Teknik pengumpulan data adalah cara-cara praktis yang ditempuh peneliti dalam mencari dan mengumpulkan data penelitian dalam bentuk pikiran, kata-kata, tindakan, peristiwa, tulisan-tulisan, gambar, dan lain-lain, sesuai dengan masalah atau fokus penelitian.

Pengumpulan data ini dilakukan dengan cara (1) Wawancara, pengumpulan data primer dengan melakukan komunikasi langsung dengan objek yang diteliti dengan mengajukan pertanyaan-pertanyaan secara khusus terkait dengan penelitian. Wawancara dilakukan kepada responden sebagai sumber data primer. (2) Kusioner, pengumpulan data yang dilakukan dan menyusun daftar pertanyaan sesuai dengan variabel dan indikator masalah yang diteliti kemudian disebarkan kepada responden agen dan broker pada PT. Jasa Indonesia cabang Medan, (3) Observasi, pengumpulan data yang langsung kelapangan untuk memastikan bahwa data yang didapat benar-benar valid, terkait dengan data dan informasi yang diterima.

\section{Teknik Analisis Data}

Analisis data yang dilakukan adalah analisa multivariat, yaitu analisis multi variabel dalam satu atau lebih hubungan. Analisis ini berhubungan dengan semua teknik statistik yang secara simultan menganalisis sejumlah pengukuran pada individu atau objek. Sebagai contoh, jika dilakukan analisis regresi sederhana, dengan satu variabel Y dan satu variabel $\mathrm{X}$, maka analisis seperti itu dikatakan bivariat, karena ada dua (bi) variabel, $\mathrm{X}$ dan $\mathrm{Y}$.

Sedangkan analisis regresi berganda dilakukan, dengan satu variabel Y. Dan dua variabel $X(X 1$ dan $X 2)$, maka analisis sudah bisa dikatakan multi variat, karena ada tiga variabel (Y, X1 dan X2). Dengan kata lain variat bisa didefinisikan sebagai suatu kombinasi linier dari variabel-variabel dengan bobot variabel yang ditentukan secara empiris. Santoso (2012:7). Sedangkan menurut Akdom dan Riduan dalam Sriyanto (2015:142) Alat analisis data, adalah objek penelitian dimana variabel yang dinyatakan lebih dari satu atau beberapa variabel maka penelitian itu merupakan analisis Regresi Linier Berganda, persamaan yang digunakan adalah sebagai berikut:

$$
Y=a+b_{1} X_{1}+b_{2} X_{2}+b_{3} X_{3}+b_{4} X_{4}+b_{5} X_{5}+e
$$

Keterangan:
$\mathrm{X}_{1}$ : Tangible
$\mathrm{X}_{4}:$ Assurance
$\mathrm{X}_{2}:$ Reliability
$\mathrm{X}_{5}$ : Empathy
a : Konstanta
$\mathrm{X}_{3}$ : Responsiveness
b : Koefisien Korelasi
e : Variabel Pengganggu

\section{Instrumen Penelitian}

Pada penelitian di bidang ilmu sosial yang antara lain seperti manajemen, psikologi, sosiologi, umumnya variabel-variabel penelitiannya dirumuskan sebagai sebuah variabel latent atau un-observed (yang sering disebut konstruk) yaitu variabel yang tidak dapat diukur secara langsung, tapi diukur melalui dimensi-dimensi atau indikator-indikator yang diamati. Biasanya indikator-indikator ini diamati dengan menggunakan kuesioner atau 
angket dengan tujuan untuk mengetahui pendapat responden tentang suatu hal sesuai dengan penelitiannya Ghozali (2016:47).

\section{Pengujian Kualitas Data}

Uji validitas digunakan untuk mengukur sah atau valid tidaknya suatu kuesioner. Maka kuesioner tersebut dinyatakan valid jika pernyataan ataupun pertanyaan pada kuesioner tersebut mampu mengungkapkan sesuatu yang akan diukur oleh kuesioner tersebut. Untuk menghasilkan data yang berkualitas dalam pengujian penelitian ini menggunakan alat bantu atau aplikasi dalam menganalisis data yang telah dikumpulkan, yaitu berbantuan Software Statitical Packge of Social Science (SPSS 23).

\section{a. Uji Validitas}

Kuesioner yang dapat dikatakan valid jika pertanyaan pada kuesioner mampu untuk mengungkapkan sesuatu yang akan diukur oleh kuesioner tersebut. Misalkan kita ingin mengukur LAYANAN seorang karyawan dan karyawan tersebut diberi empat pertanyaan maka pertanyaan tersebut harus dapat secara tepat mengungkapkan tingkat KEPUASAN. Jadi validitas ingin mengukur apakah pertanyaan dalam kuesioner yang sudah kita buat betul-betul dapat mengukur apa yang ingin kita ukur. Mengukur validitas dapat dilakukan dengan tiga cara adalah sebagai berikut:

Melakukan korelasi antar skor butir pertanyaan dengan total skor konstruk atau variabel. Dalam hal ini melakukan korelasi masing-masing skor layananl, layanan2, layanan3, dan layanan4 dengan total skor KEPUASAN. Hipotesis yang diajukan:

$\mathrm{H}_{0}$ : Skor butir pertanyaan berkorelasi positif dengan total skor konstruk

$\mathrm{H}_{\mathrm{a}}$ : Skor butir yang tidak berkorelasi positif dengan skor total konstruk

Uji signifikansi dilakukan dengan membandingkan nilai $r$ hitung dengan $r$ tabel untuk degree of freedom $(\mathrm{df})=\mathrm{n}-2$, dalam hal ini $\mathrm{n}$ adalah jumlah Sampel. Pada kasus akan kita konstruk LAYANAN jumlah Sampel $(n)=395$ dan besarnya df dapat dihitung $395-2=$ 393 dengan $\mathrm{df}=393$ dan alpha $=0.05$ didapat $\mathrm{r}$ tabel $=0.0827$ (lihat $\mathrm{r}$ tabel pada $\mathrm{df}=393$ dengan uji dua sisi).

Untuk menguji apakah masing-masing indikator layanan1 sampai layanan4 valid atau tidak, kita lihat tampilan output Cronbach Alpha pada kolom Correlated Item-Total Correlation baik untuk konstruk LAYANAN dan KEPUASAN. Bandingkan nilai Correlated Item - Total Correlation dengan hasil perhitungan $\mathrm{r}$ tabel $=0.0827$. Jika $\mathrm{r}$ hitung lebih besar dari $r$ tabel dan nilai positif maka butir atau pertanyaan atau indikator tersebut dinyatakan valid.

Untuk indikator konstruk LAYANAN nilai $r$ semua di atas nilai $r$ tabel maka dapat disimpulkan semua indikator valid. Begitu juga dengan nilai $r$ untuk indikator konstruk KEPUASAN semua nilai $r$ hitung di atas nilai $r$ tabel, maka dapat disimpulkan semua indikator valid. Selain membandingkan $r$ hitung dengan $r$ tabel, uji signifikansi dapat juga dilakukan lewat uji t dengan prosedur:

1. Ambil sembarang $r$ hitung, misal indikator layanan1 dengan nilai $r$ hitung $=0.0829$

2. Hitung nilai t hitung dengan rumus:

$$
\mathrm{t}=\frac{r}{\sqrt{\frac{1-r^{2}}{N-2}}}
$$

3. Bandingkan nilai t hitung ini dengan t tabel pada alpha $=0,05$ dan $\mathrm{df}=\mathrm{N}-2=393$ atau nilai $t$ tabel $=1.6487$

4. Karena nilai t hitung $>\mathrm{t}$ tabel, maka $\mathrm{H}_{0}$ tidak dapat ditolak atau $\mathrm{r}$ memang berkorelasi positif atau indikator kepuasan1 adalah valid.

\section{b. Uji Reliabilitas}




\section{JESYA}

JURNAL EKONOMI \& EKONOMI SYARIAH

Jurnal Ekonomi \& Ekonomi Syariah Vol 5 No 1, Januari 2022

E-ISSN : 2599-3410 | P-ISSN : 2614-3259

DOI : https://doi.org/10.36778/jesya.v5i1.580

Uji reliabilitas adalah alat untuk mengukur kuesioner yang merupakan indicator dari variabel konstruk. Pada penelitian ini dihitung dengan menggunakan uji statistik Cronbach Alpha. Pengambilan keputusan berdasarkan jika nilai Alpha melebihi 0,60 maka pertanyaan variabel tersebut reliabel dan jika nilai Alpha kurang dari 0,60 maka pertanyaan variabel tersebut tidak reliabel (Imam Ghozali, 2006: 46).

\section{Pengujian Hipotesis}

Untuk memperoleh kesimpulan dari analisis ini maka terlebih dahulu dilakukan pengujian hipotesis yang dilakukan secara menyeluruh atau simultan (Uji F). Dan secara parsial (Uji t) yang dijelaskan sebagai berikut:

1. Uji Parsial (Uji t)

Uji t digunakan untuk menguji atau membandingkan rata nilai sesuatu sampel dengan nilai lainnya. Uji t dilakukan untuk mengetahui apakah semua variabel independen secara parsial berpengaruh signifikan terhadap variabel dependen. Pengujian dilakukan dengan tingkat yang ditentukan adalah $95 \%$ dengan tingkat signifikan sebesar $0,5 \%$ dan degree of freedom (df) $\mathrm{n}-\mathrm{k}$ membandingkan $\mathrm{t}$ hitung dengan $\mathrm{t}$ tabel maka Ho ditolak dan Ha diterima. Berarti bahwa variabel independen mempunyai pengaruh bermakna terhadap variabel independen tidak mempunyai pengaruh terhadap variabel dependen.

2. Uji Simultan ( Uji F )

Untuk pengujian-pengujian variabel independen secara bersamaan digunakan statistik Uji F (F-test) dilakukan untuk melakukan apakah model pengujian hipotesis yang dilakukan tepat. Uji F dilakukan untuk mengetahui apakah variabel secara bersamaan berpengaruh terhadap variabel dependen. Analisis uji F ini dilakukan dengan membandingkan F hitung dengan $\mathrm{F}$ tabel dengan tingkat kepercayaan alpha yang ditentukan adalah $5 \%=\mathrm{F}$ tabel 2,30, dengan membandingkan $\mathrm{F}$ hitung dengan $\mathrm{F}$ tabel yaitu apabila $\mathrm{F}$ hitung $>\mathrm{F}$ tabel atau $\mathrm{p}$ value < a, maka Ho ditolak dan Ha diterima. Berarti bahwa variabel independen secara bersamaan mempunyai pengaruh terhadap variabel dependen. Sebaliknya, apabila F hitung $<$ F tabel atau P value > a, maka Ho diterima dan Ha ditolak. Hasilnya tidak signifikan yang berarti bahwa variabel independen tidak mempunyai pengaruh terhadap variabel dependen.

3. Koefisien Determinan

Koefisien determinasi (R2 ) pada intinya mengukur seberapa jauh kemampuan model dalam menerangkan variasi variabel terikat. Nilai adjusted R2 yang kecil atau mendekati nol berarti kemampuan variabel bebas dalam menjelaskan variabel-variabel terikat sangat terbatas. Semakin tinggi nilai adjusted R2 maka semakin tinggi variabel bebas dapat menjelaskan variasi variabel terikat Menurut Ghozali (2016:95)

\section{HASIL DAN PEMBAHASAN}

Populasi dalam penelitian ini adalah konsumen PT. Asuransi Jasa Indonesia cabang Medan, yang berasal dari agen, broker dan perorangan (umum), dengan jumlah populasi 29.469 polis/konsumen data yang dihimpun dari 2015-2019. Dalam penelitian ini penulis menggunakan teknik probability sampling yaitu proportionate stratified random sampling. Populasi dari penelitian ini adalah jumlah polis asuransi dari agent dan broker dari tahun 2015-2019 yang berjumlah 394 orang.

Teknik pengumpulan data yang dilakukan adalah dengan cara menyusun daftar pertanyaan sesuai dengan variabel dan indikator masalah yang diteliti kemudian disebarkan kepada responden agen dan broker pada PT. Jasa Indonesia cabang Medan..

\section{Hasil Pengujian Validitas}




\section{JESYA}

JURNAL EKONOMI \& EKONOMI SYARIAH

Jurnal Ekonomi \& Ekonomi Syariah Vol 5 No 1, Januari 2022

E-ISSN : 2599-3410 | P-ISSN : 2614-3259

DOI : https://doi.org/10.36778/jesya.v5i1.580

Hari pengujian validitas terhadap 30 responden menunjukkan variabel tangibles (1), reliability (0.597), responsiveness (0.334), assurance (0.298), empathy (0.318) dan Kepuasan Konsumen (0.335). Pada setiap nilai butir soal pernyataan dinyatakan valid, karena nilai setiap $r$ hitung lebih besar dari nilai $r$ tabel (0.296). Sedangkan pengujian terhadap 394 responden dapat dinyatakan variabel tangibles (1), reliability (0.359), responsiveness (0.206), assurance (0.329), empathy (0.271) dan Kepuasan Konsumen (0.131). Jadi pada setiap nilai butir soal pernyataan dinyatakan valid, karena nilai setiap $r$ hitung lebih besar dari nilai $r$ tabel (0.0828).

\section{Hasil Pengujian Reliabilitas}

Hasil pengujian pada reliabilitas kuesioner variabel kepuasan konsumen dengan nilai alpha $(0,730)$ dinyatakan reliabel, tangibles dengan nilai alpha $(0,706)$ sangat reliabel, reliability dengan nilai alpha $(0,670)$ sangat reliabel, responsiveness dengan nilai alpha $(0,784)$ reliabel, assurance dengan nilai alpha $(0,726)$ dinyatakan reliabel, dan empathy dengan nilai alpha $(0,686)$ reliabel. Sedangkan pengujian terhadap 394 responden variabel kepuasan konsumen dengan nilai alpha $(0,668)$ dinyatakan reliabel, tangibles dengan nilai alpha $(0,788)$ sangat reliabel, reliability dengan nilai alpha $(0,794)$ sangat reliabel, responsiveness dengan nilai alpha $(0,779)$ reliabel, assurance dengan nilai alpha $(0,661)$ dinyatakan reliabel, dan empathy dengan nilai alpha $(0,661)$.

\section{Hasil Analisis Korelasi Parsial}

Pada setiap nilai yang didapatkan berpengaruh positif dan kuat serta signifikan terhadap kepuasan konsumen dengan nilai koefisien korelasi tangible sebesar 1, reliability 0,181, responsiveness sebesar 0,35, assurance sebesar 0,302, empathy sebesar 0,249 dan nilai significance (2-tailed) adalah $0,000<(0,05)$ maka dari data ini dinyatakan bahwa ada hubungan yang positif dan signifikan antara variabel layanan dengan kepuasan konsumen.

\section{Hasil Uji Multikolonieritas}

Kualitas tangible, reliability, responsiveness, assurance berpengaruh positif dan signifikan terhadap kepuasan konsumen. Hal ini dapat dilihat dari hasil regresi linier berganda nilai thitung tagible 0,529 dengan nilai signifikan sebesar 0,602. Sedangkan nilai t hitung reliability 0,585 dengan nilai signifikan sebesar 0,564. Responsiveness dengan nilai t hitung 0,948 dengan nilai signifkan 0,352. Sedangkan nilai t hitung Assurance sebesar 0,314 dengan nilai signifikan 0,756. Dan kualitas empathy berpengaruh negatif dan signifikan terhadap kepuasan konsumen. Hal ini dapat dilihat dari hasil regresi linier berganda nilai empathy berpengaruh negatif dengan nilai - 0,232 dan signifikan sebesar 0,819 .

\section{Hasil Uji F Pada Regresi Linier Berganda}

Nilai $F$ hitung adalah sebesar 6,337. Sedangkan nilai $F$ tabel sebesar $=3,02$. Nilai F hitung > $\mathrm{F}$ tabel, maka $\mathrm{H}_{0}$ ditolak, Ha diterima, ini artinya Ha diterima, yaitu terdapat pengaruh yang signifikan secara simultan antara variabel kualitas layanan terhadap kepuasan konsumen.

\section{Hasil R Square}

Nilai $\mathrm{R}^{2}$ ( $\mathrm{R}$ square) adalah 0,785 . sehingga di dapat bahwa besarnya pengaruh variabel kualitas layanan terhadap kepuasan konsumen adalah 78,5\% sedangkan sisanya 21,5\% dipengaruhi oleh variabel lain di luar penelitian. Secara umum penelitian ini menunjukkan hasil yang cukup memuaskan. Hal ini ditunjukkan berdasarkan dari analisis R Square yang didapatkan sebesar 0,785 sehingga besarnya pengaruh variabel kualitas layanan berpengaruh terhadap kepuasan konsumen sebesar 78,5\%. 


\section{KESIMPULAN}

Berdasarkan hasil yang telah diperoleh dari hasil analisis yang telah dilakukan baik secara deskriptif maupun statistik diperoleh kesimpulan sebagai berikut :

1. Kualitas tangible berpengaruh positif dan signifikan terhadap kepuasan konsumen dengan nilai signifikan sebesar 0,602 .

2. Kualitas reliability berpengaruh positif dan signifikan terhadap kepuasan konsumen dengan nilai signifikan sebesar 0,564 .

3. Kualitas responsiveness berpengaruh positif dan signifikan terhadap kepuasan dengan nilai signifkan 0,352 .

4. Kualitas assurance berpengaruh positif dan signifikan terhadap kepuasan konsumen dengan nilai signifikan 0,756 .

5. Kualitas empathy berpengaruh negatif dan signifikan terhadap kepuasan konsumen dengan nilai - 0,232 dan signifikan sebesar 0,819.

6. Nilai F hitung adalah sebesar 6,337 dan nilai $F$ tabel sebesar $=3,02$. Hal ini menandakan F hitung $>$ F table, ini artinya Ha diterima atau terdapat pengaruh yang signifikan secara simultan antara variabel kualitas layanan terhadap kepuasan konsumen.

7. Hasil R Square adalah 0,785. sehingga dapat disimpulkan bahwa besarnya pengaruh variabel kualitas layanan terhadap kepuasan konsumen adalah 78,5\% sedangkan sisanya $21,5 \%$ dipengaruhi oleh variabel lain di luar penelitian.

\section{DAFTAR PUSTAKA}

Anggabrata, dan Rahanata. (2015). Pengaruh Kualitas Pelayanan Terhadap Kepuasan Nasabah Pada PT BPR Balidana Niaga Denpasar. E-Jurnal Manajemen Unud, Vol. 4, No. 5, $2015: 1196-1205$

Asura. (2021). Perbedaan Agen dan Broker Asuransi Yang Perlu Anda Ketahui, diakses pada 07 Juli 2021 https://www.asura.co.id/blog/perbedaan-agen-dan-broker-asuransiyang-perlu-anda-ketahui

Barqah, Amanta, H. Hrp (2019) Pengaruh Kualitas Layanan Terhadap Kepuasan Nasabah Asuransi Kerugian Di PT Asuransi Asei Indonesia Persero Cabang Medan. Skripsi Ekonomi dan Bisnis Islam Universitas Islam Negeri Sumatera Utara 2019.

Dimyati, Mohammad, (2005). Pemasaran Jasa. Fakultas Ekonomi Universitas Jember

Dutka, Alan, 2008. AMA Hand Book for Customer Satisfaction. NTC Business Book,. Lincolnwood, Illinois.

Elisabeth, R. Simamora. (2007) Analisis Faktor-Faktor Yang Membangun Kepuasan Nasabah Untuk Meningkatkan Loyalitas Pelanggan (Studi Empiris Nasabah PT. Bank Tabungan Negara Cabang Semarang). Tesis Program Studi Magister Manajemen Program Pasca Sarjana, Universitas Diponegoro Semarang 2007.

Fauzi, Wetria. (2019) Hukum Asuransi Di Indonesia, (Cetakan Pertama). Padang: Andalas University Press

Ghozali, Iman (2016) Aplikasi Analisis Multivariette Dengan Program IBM SPSS 23 Semarang: Badan Penerbit Universitas Diponegoro (Cetakan VIII) Semarang: Badan Penerbit Universitas Diponegoro.

Haris, Henry. (2017). Pengaruh Kepuasan Kerja dan Komitmen Organisasi Terhadap Kualitas Layanan di PT. Asuransi Jasindo (Persero) Kantor Cabang Korporasi dan Ritel Bandung. Jurnal Ekonomi Manajemen Sumber Daya : Vol. 19, No. 2, Desember 2017 


\section{JESYA}

JURNAL EKONOMI \& EKONOMI SYARIAH

Jurnal Ekonomi \& Ekonomi Syariah Vol 5 No 1, Januari 2022

E-ISSN : 2599-3410 | P-ISSN : 2614-3259

DOI : https://doi.org/10.36778/jesya.v5i1.580

Indonesia Spss, (2021). Makna Koefisien Determinasi R Square. SPSS: https://www.spssindonesia.com/2017/04/makna-koefisien-determinasi-r-square.html (2021, 07 September)

Ivan, Muttaqin. (2013) Analisis Pengaruh Kualitas Layanan Terhadap Kepuasan Nasabah Pada Asuransi Jasaraharja Putera Semarang. Skripsi Ekonomi Bisnis Universitas Diponegoro Semarang 2013.

Jasindo (2021). Tentang Kami Visi Misi: http://www.jasindo.co.id/tentang-kami/visi_misi. (2021, 07 April)

Kotler, P. (2009). Manajemen Pemasaran. Jakarta: Erlangga

Mastura, Zainatun. (2018). Pengaruh Kualitas Pelayanan Dan Kepercayaan Nasabah Terhadap Kepuasan Nasabah. Skripsi Ekonomi dan Bisnis Islam Universitas Islam Negeri Ar-Raniry Banda Aceh 2018.

Muhammad, Abdulkadir. (2006) Hukum Asuransi Indonesia (Cetakan Keempat). Bandung: PT Citra Aditya Bakti.

Mulyana dkk. (2019). Pengaruh Kualitas Layanan Terhadap Kepuasan Dan Dampaknya Terhadap Kepercayaan Konsumen Asuransi Kendaraan Bermotor Pada Asuransi Jasindo (Persero) Kantor Cabang Palu

Mustakim, Zainal, dkk. (2018) Pengaruh kualitas layanan terhadap kepuasan dan dampaknya terhadap kepercayaan tertanggung asuransi kendaraan bermotor pada asuransi jasindo (persero) kantor cabang palu. Jurnal Katalogis: Vol 6 Nomor 4 April $2018 \mathrm{hlm}$ 58-70

Raharja dan Khasanah (2015). Analisis Pengaruh Kualitas Layanan, Kualitas Produk, Dan Nilai Pelanggan Terhadap Kepuasan Pelanggan (Studi pada konsumen PT. Prudential Life Assurance Semarang.)

Santoso, Singgih (2012) Aplikasi SPSS Pada Statistik Multivariat. Jakarta: PT. Elexmedia Komputindo

Sandi, Gusti. (2019). Pengaruh Tarif Premi, Dan Kualitas Layanan Terhadap Kepuasan Konsumen Dalam Meningkatkan Loyalitas Konsumen PT. Asuransi Jiwasraya (Persero) Cabang Medan Selatan. (Tesis Magister, Universitas Sumatera Utara 2019).

Scribd

Sejarah-Gedung-Jasindo-Medan: https://www.scribd.com/document/438448380/Sejarah-Gedung-Jasindo-Medan. (2021, 07 April)

Sriyanto. (2015). Pengaruh Kualitas Layanan Terhadap Kepuasan Nasabah PT. Bank Rakyat Indonesia (Persero), Tbk Unit Sangatta Lama Diakses:https://media.neliti.com/media/publications/55958-ID-pengaruh-kualitaslayanan-terhadap-kepua.pdf

Sugiyono (2017). Metode Penelitian Kuantitati, Kualitatif dan R \& D.. Alfabeta, Bandung Suryani, Ade Irma. S (2012). Analisis Pengaruh Kualitas Layanan Terhadap Tingkat Kepuasan Nasabah Pada PT. Asuransi Takaful Umum Cabang Pekanbaru. Skripsi Manajemen Universitas Islam Negeri Sultan Syarif Kasim Riau Pekanbaru 2012.

Suryawan, Sheehan dan Dharmayanti, Diah, 2013. Analisa Hubungan Antara Experential Marketing, Customer Satisfaction Dan Customer Loyalty Cafe Nona Manis Grand City Mall Surabaya. Jurnal Manajemen Pemasaran: Vol. 1, No. 2, (2013) 1-10.

Thio, S. (2001). Membangun Service Quality untuk Mencapai Kepuasan Konsumen di Industri Hospitality. Jurnal Manajemen \& Kewirausahaan, Vol. 3, No. 1, halaman 61 $-71$

Tjiptono, F. (2012). Service Management Mewujudkan Layanan Prima. Yogyakarta: Andi Offset 
Winarta, R.C dan Kunto,Y.S. (2013). Pengaruh Kualitas Layanan Rumah Makan Bromo Asri Terhadap Kepuasan. Jurnal Manajemen Pemasaran Vol. 1, No. 1, (2013) 1-10 1.

Wikipedia. (2021). Asuransi Indonesia:

https://id.wikipedia.org/wiki/Asuransi_Jasa_Indonesia. (2021, 27 Agustus). 